\title{
Foraging by little auks in the distant marginal sea ice zone during the chick-rearing period
}

\author{
Dariusz Jakubas $\cdot$ Lech Iliszko $\cdot$ Katarzyna \\ Wojczulanis-Jakubas $\cdot$ Lech Stempniewicz
}

Received: 7 December 2010 / Revised: 5 May 2011 / Accepted: 17 May 2011 / Published online: 3 June 2011

(C) The Author(s) 2011. This article is published with open access at Springerlink.com

\begin{abstract}
During the chick-rearing period, little auks Alle alle adopt a bimodal foraging strategy, alternating long trips with several short ones. It has been postulated that they reach more remote areas during long feeding trips than during short ones. However, the range of their foraging flights has never actually been measured. The aims of this study were to find the exact location of the little auk feeding grounds and to investigate whether they reach remote areas during long foraging trips using miniature GPS and temperature loggers. The study was conducted in 2009 in Magdalenefjorden $\left(79^{\circ} 34^{\prime} \mathrm{N}, 11^{\circ} 04^{\prime} \mathrm{E}\right)$, one of the main breeding grounds of little auks on Spitsbergen. The temperature logger records indicated that during short trips, little auks visit warmer waters (situated close to the colony) than during long ones. The tracks of two GPS-equipped birds indicated that during long trips little auks foraged in the distant, foodabundant marginal sea ice zone, at least $100 \mathrm{~km}$ away from the colony. During long trips, birds make several stops at sea, perhaps sampling the foraging area with respect to prey distribution. Since food conditions near the studied colony are usually suboptimal, little auks may be exploiting distant feeding areas to compensate for the poorer-quality food available at nearby foraging grounds. The extended duration of long foraging trips may enable birds to collect food for chicks on food-abundant, remote foraging grounds as well as acquire, process and excrete food needed for selfmaintenance, reducing the costs of flight to the colony.
\end{abstract}

D. Jakubas · L. Iliszko $\cdot$ K. Wojczulanis-Jakubas ·

L. Stempniewicz $(\bowtie)$

Department of Vertebrate Ecology and Zoology, University of Gdańsk, Legionów 9, 80-441 Gdańsk, Poland e-mail: biols@univ.gda.pl
Keywords Little Auk $\cdot$ Alle alle $\cdot$ Foraging range · Bimodal foraging strategy $\cdot$ Spitsbergen

\section{Introduction}

During the chick-rearing period, pelagic seabirds often make foraging trips to remote locations but consistently return to a central place, the colony, to deliver food to their nestlings. Several species of Procellariiformes perform foraging trips of bimodal duration, alternating a long trip with several consecutive short trips (e.g. Chaurand and Weimerskirch 1994; Weimerskirch et al. 1994, 1997; Granadeiro et al. 1998; Booth et al. 2000; Catard et al. 2000). It has also been observed in some species that during long foraging trips, birds reach more remote areas than during short ones (Chaurand and Weimerskirch 1994; Weimerskirch et al. 1994). It has been postulated that short foraging trips enable the parents to provision the brood at a maximal rate. During long trips, they forage mainly to restore their own body reserves (Weimerskirch 1998).

Such a bimodal foraging strategy has recently been described in the little auk (Alle alle; Steen et al. 2007; Welcker et al. 2009; Wojczulanis-Jakubas et al. 2010). This small planktivorous alcid breeding colonially in the high Arctic is considered to be the most numerous seabird in the Palaearctic. Both partners incubate a single egg as well as brood (for the few first days) and feed the chick. The food is carried by the adults in the gular pouch (Stempniewicz 2001). Little auks forage almost exclusively on planktonic crustaceans, mainly copepods, focusing on species associated with cold Arctic waters, which are larger and much richer in energy than those from warmer Atlantic waters (Karnovsky et al. 2003; Jakubas et al. 2007). The distribution of cold Arctic waters along the west coast of Spitsbergen 
varies spatially and seasonally (e.g. Walczowski and Piechura 2007), affecting the accessibility of the zooplankton items preferred by little auks.

The food trip distances of breeding little auks have never been measured directly. Owing to the high cost of foraging (the time and energy expended on feeding combined with the high cost of diving and flapping flight; Gabrielsen et al. 1991; Konarzewski et al. 1993), little auks would be expected to avoid increasing flight distance and to forage close to the colony. Welcker et al. (2009) calculated theoretical maximum foraging ranges of short trips of 12 and $33 \mathrm{~km}$ and long trips of 130 and $219 \mathrm{~km}$ in two colonies studied on Spitsbergen, based on the mean flight times of parent birds equipped with miniature time-depth recorders. The range of the short trips corresponds well with the tens of kilometres reported from other colonies (reviewed in Stempniewicz 2001). Also, the ranges of long trips are in agreement with observations of little auks of unknown breeding status, feeding 100-150 km from the nearest colony (Brown 1976; Węsławski et al. 1999; Joiris 2000). There are also other indirect observations suggesting that little auks forage on distant feeding grounds, such as the occurrence in the chick diet of food items characteristic of the shelf break zone some $150 \mathrm{~km}$ away from the colony (Steen et al. 2007).

The aims of this study were to measure directly, using miniature loggers, the range of little auk foraging flights, to pinpoint the exact locations of their feeding grounds and to investigate whether they reach remote areas during long trips.

\section{Materials and methods}

The study was conducted in the little auk breeding colony on the Alkekongen slopes $\left(79^{\circ} 34^{\prime} \mathrm{N}, 11^{\circ} 04^{\prime} \mathrm{E}\right)$ in Magdalenefjorden (NW Spitsbergen) during the chick-rearing period in 2009. The area is known to be one of the main breeding grounds of little auks on Spitsbergen (Isaksen 1995). In this area, the perennial sea ice marginal zone (abundant in amphipods and copepods; Arndt and Swadling 2006) is often situated relatively close to the coast (100$150 \mathrm{~km}$ ) during the breeding season. The regular presence of ice-associated prey items in the food brought to nestlings by parent birds from this colony (Kwasniewski et al. 2010) and observed concentrations of little auks in the sea ice marginal zone in other parts of the Greenland Sea (Joiris 2000; Joiris and Falck 2011) strongly suggest that little auks from NW Spitsbergen colonies are capable of reaching the marginal sea ice zone during their foraging trips. In July 2009, the marginal sea ice zone was situated at a distance of 100-150 km from the colony (ice maps of Meteorologisk Institutt met.no downloaded from http://www. polarview.met.no/).
To investigate the distance of foraging flights and the patterns of the birds' activity during their foraging trips, we used two types of loggers, recording temperature and position. The temperature loggers (ECOTONE ETL 1, Ecotone, Sopot, Poland; oval, $14 \times 15 \times 4 \mathrm{~mm}$, weight $1.0 \mathrm{~g}$ ) recorded temperature with time stamps (range from $-40^{\circ} \mathrm{C}$ to $+85^{\circ} \mathrm{C}$, accurate to $0.5^{\circ} \mathrm{C}$ ) at sampling intervals of $60 \mathrm{~s}$. The logger memory of 8,192 records allowed 5.7 days of continuous data storage. Birds were caught on the nest during the early chick-rearing period and the temperature loggers attached to the belly feathers using LOCTITE 4860 cyanoacrylate glue (Henkel Corp., Rocky Hill, Connecticut, USA) at approximately the midpoint of the centre line of the body. The logger together with the potting mass $(1.5 \mathrm{~g})$ was equivalent to ca $0.9 \%$ of the birds' body mass (mean $166.2 \pm \mathrm{SD} 11.60 \mathrm{~g}, N=52$ adults measured during the early chick-rearing period, including birds equipped with loggers). Birds were released back into the nest after $10 \mathrm{~min}$ of handling. Regular checks at the nest started $24 \mathrm{~h}$ after attachment and were continued until the bird could be caught and the data downloaded from the logger. We attached 18 loggers to 13 individuals. In five instances, because the loggers came unstuck, after a few downloads, the loggers had to be replaced with new ones. We retrieved 14 of the 18 temperature loggers; some of them were downloaded several times. In total, we obtained $1,930 \mathrm{~h}$ of temperature records from nine individuals. Data series from two birds were too short for analysis and were rejected, as were those recorded by loggers almost completely insulated by feathers. Of the remaining $1,118 \mathrm{~h}$ of records, $186 \mathrm{~h}$ related to the birds' stay in the colony. Ultimately, to show the distribution of foraging trip durations, we used $932 \mathrm{~h}$ of temperature records obtained from seven birds. From this, $475 \mathrm{~h}$ was used to show the spatial differentiation of temperatures recorded during their stay at sea (exclusively in the foraging area, after excluding $457 \mathrm{~h}$ of records during flights to and from the colony).

All 13 logger-equipped individuals, including four birds that we failed to recapture, were regularly observed in the colony with full gular pouches, indicating that despite this burden, they were able to forage and deliver food to chicks. Visual inspection of the graphs plotted with a custom-made application working in the MS Excel environment distinguished three main types of little auk activity: presence in the colony, flight and presence on the water (Tremblay et al. 2003; Welcker et al. 2009). A sudden and steep increase in temperature $\left(10-15^{\circ} \mathrm{C}\right.$ above the air temperature) was interpreted as arrival at the colony. The subsequent period of high temperatures was considered to represent presence in the colony. A decrease in temperature approaching the level considered to be flight, recorded after that period, was interpreted as departure from the colony. A further sudden and steep decrease in temperature was 


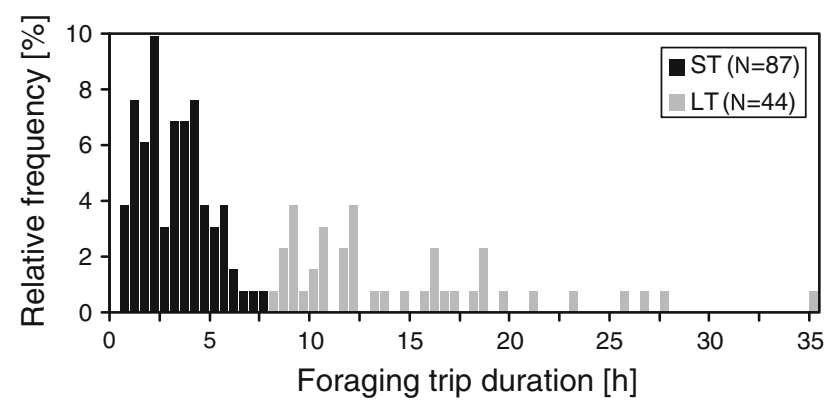

Fig. 1 Frequency distribution of little auk foraging trip durations. Short trips are denoted by black bars and long trips by grey bars

regarded as landing on the water and presence on the sea surface. Subsequent rapid increases in temperature were interpreted as take-off from the water and flight. The temperature levels associated with particular activities varied among individuals, presumably depending on the exact location of the logger on the bird's body and the extent to which it was covered by feathers. Although the distribution of trip durations was bimodal (Fig. 1), it was not a straightforward matter to determine the exact location of the cut-off value separating short and long trips on the basis of frequency distributions alone. The bimodal distribution of the full datasets can be considered to be two separate lognormal distributions of short and long trips. We regarded the cut-off value to be best that minimized the sum of the variances of both trip types, given their log-normal distribution (Welcker et al. 2009). The derived cut-off value of $460 \mathrm{~min}$ $(7.7 \mathrm{~h})$ corresponded well with the $7.6 \mathrm{~h}$ calculated by Welcker et al. (2009) for the nearby colony at Kongsfjorden ( $75 \mathrm{~km}$ south of Magdalenefjorden). Since the temperatures recorded by the loggers were not standardized, as the devices were insulated by feathers to different extents, raw temperature data were not analysed. Instead, minimal values and the interquartile range of temperatures recorded exclusively during the little auks' stay in the foraging area were compared between the short and long trips for each bird separately (Fig. 3).

The global positioning system (GPS) loggers (ECOTONE PATRON EP-2, Ecotone, Sopot, Poland; printed circuit board size-length $\times$ width: $26 \times 15 \mathrm{~mm}$; including battery and potting $40 \times 17 \times 9 \mathrm{~mm}$, weight $4.9-5.2 \mathrm{~g}$, field tested accuracy of GPS receiver $\pm 50 \mathrm{~m}$ ) recorded time and position at sampling intervals of $15 \mathrm{~min}$. Up to 1,000 GPS fixes could be stored in the logger memory. The time between recorded fixes can vary depending on the time spent by the bird under water (satellite signal unavailable). Birds were caught on their nests during the chickrearing period, and GPS loggers were attached to the central back feathers with one longitudinally and two transversally applied 10-mm-wide strips of code 4965 Tesa tape (Tesa Tape Inc., Charlotte, NC, USA; Wilson et al. 1997).
The birds were released back into the nest after handling. The total handling time was $25 \mathrm{~min}$. The total logger mass including attachment (5.4-5.7 g) was equivalent to $3.2-3.4 \%$ of the mean little auk body mass (mean 166.2 \pm SD $11.60 \mathrm{~g}, N=52$ adults measured during the early chickrearing period, including birds equipped with loggers). The loggers were able to operate for 3 days under a cloudless sky, but battery depletion was much faster when operating under rocks or under water. Regular checks at the nests started after $24 \mathrm{~h}$ and were conducted until the bird could be recaptured. We retrieved four of the twelve attached loggers and successfully downloaded data from two of them. One of the successfully recaptured individuals was observed in the colony with a full gular pouch, and three others were caught directly on the nest. Of the eight birds with attached but unretrieved loggers, two were seen at least once again in the colony (without food in the gular pouch), and six were not sighted again in the colony. Chick survival up to 20 days (chicks that disappeared from the nest after 20 days of age were considered as fledged; Harding et al. 2004; Welcker et al. 2009) was monitored in six accessible nests of GPS-equipped birds. In five of them, chicks survived up to 20 days and in one nest the chick disappeared after 14 days, probably taken by an Arctic fox (Alopex lagopus) or a glaucous gull (Larus hyperboreus). Excluding GPS fixes taken in the colony, a total of 111 locations were obtained from the two birds (41 and 70). Both successfully retrieved GPS data sets were recorded on 29 July during the early chick-rearing period (chicks 13 and 14 days old, respectively). The tracks from the GPS loggers were visualized in Google Earth.

\section{Results}

The temperature logger data indicate that during the chickrearing period, little auks from Magdalenefjorden adopted a bimodal foraging trip strategy, alternating one long trip with several consecutive, short foraging trips (Fig. 1). The mean durations of the short and long trips were $3.3 \pm \mathrm{SE}$ $0.18 \mathrm{~h}(N=87)$ and $14.7 \pm \mathrm{SE} 0.92 \mathrm{~h}(N=44)$, respectively.

The distribution of temperatures recorded by the loggers attached to seven little auks during their stay in the foraging area differed between the long and the short trips. Generally, three temperature peaks occurred during the long trips-the first (T1 in Figs. 2, 3) with very low values (close to $0^{\circ} \mathrm{C}$ ), the second (T2 in Figs. 2, 3) with temperatures overlapping those recorded during the short flights, and the third (T3 in Figs. 2, 3) with considerably higher values compared with the first two peaks. One peak and a much smaller range of temperatures characterized the short trips (T2 in Figs. 2, 3). The interquartile range of the 


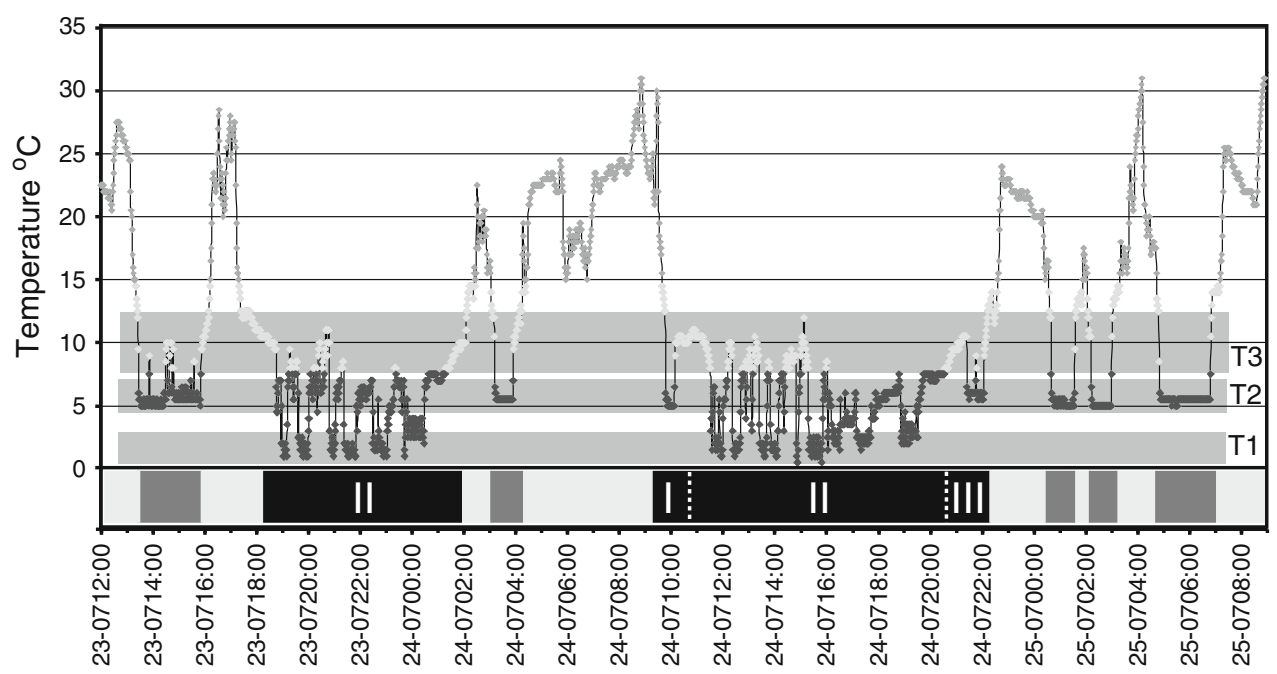

Fig. 2 A typical daily pattern of temperature records obtained from a logger-equipped little auk, showing the bimodal lengths of foraging trips. Particular sectors of the temperature curve represent three main types of little auk activity: flight-light grey, presence in the colonydark grey, presence on the water-black. Bar T1 indicates the temperature level recorded only during the long trips, bar T2 the level of temperatures recorded during the long and short trips and bar T3 the temperature level reflecting flights between areas with temperature levels T1 and T2. The particular parts of the bar below the curve indicate periods of presence in the colony (light grey), short (dark grey) and long (black) foraging trips. The numbers I, II, III on the black bars indicate the phases of stays in the foraging area during the long trip. The example illustrated is based on $67 \mathrm{~h}$ of data from an individual parent bird rearing a 5-7-day-old chick temperatures recorded during the birds' stay at sea was $3.0-7.0^{\circ} \mathrm{C}$ during long trips (mean $\pm \mathrm{SD}: 5.5 \pm 1.35^{\circ} \mathrm{C}$ ) and $0.5-1.5^{\circ} \mathrm{C}$ during the short trips (mean $\pm \mathrm{SD}$ : $\left.0.9 \pm 0.53^{\circ} \mathrm{C}\right)$. The temperatures close to $0^{\circ} \mathrm{C}(\mathrm{T} 1$ in Figs. 2, 3) were recorded only during the long trips. The minimal temperatures recorded in the feeding area during the long trips were $3.0-6.5^{\circ} \mathrm{C}$ lower than those during the short trips (mean difference \pm SD: $4.3 \pm 1.19^{\circ} \mathrm{C}$ ).

Analysis of the temperatures recorded by the loggers revealed that in $61 \%$ of the 44 long trips performed by all seven individuals, there are three distinct phases of the stay in the foraging area during such a trip. The first phase (I in Fig. 2) included the first landing at sea in the warm-water area with temperatures similar to those recorded during short foraging trips (T2 in Figs. 2, 3). The second phase (II in Figs. 2, 3) was characterized by low temperatures, often close to $0^{\circ} \mathrm{C}$, followed by rapid fluctuations (T1-T3 in Fig. 2), probably reflecting foraging in cold water alternating with a series of short, local flights. The third phase (III in Fig. 2) included the last landing before the return to the colony, again in the warm-water area with temperatures similar to those recorded during the first phase and during the short trips (T2 in Figs. 2, 3).

The first GPS fixes of both individuals after leaving the colony were recorded in the shelf break zone at distances of 12 and $21 \mathrm{~km}$ from the colony (the first and second individual, respectively; Fig. 4). They remained there for at least 0.8 and $0.7 \mathrm{~h}$, respectively, changing their location within a small range $(0.5-5.6 \mathrm{~km})$. The second stop (recorded only in the first bird; the other bird did not land before the end of recording) was $13 \mathrm{~km}$ from the first landing $(26 \mathrm{~km}$ from the colony). This bird spent at least $1.1 \mathrm{~h}$ there, changing location within a small range $(0.6-5.0 \mathrm{~km})$. After the third landing, recorded $25 \mathrm{~km}$ from the previous one $(56 \mathrm{~km}$ from the colony), the same individual spent $0.7 \mathrm{~h}$ within a range of $0.5 \mathrm{~km}$. The next positions were recorded most probably during flight (each one at a different time). The last recorded positions of both little auks were close to the marginal sea ice zone, at distances of 100 and $110 \mathrm{~km}$ (in a straight line) from the colony (111 and $128 \mathrm{~km}$ measuring the actual tracks of birds), respectively (Fig. 4). The times elapsing between the first landing after departure from the colony and the last recorded position close to the marginal sea ice zone were 4.3 and $4.5 \mathrm{~h}$, respectively.

\section{Discussion}

To our knowledge, this is the first study to directly investigate the range of foraging flights and the location of the feeding grounds of chick-rearing little auks. Though based on only a small sample and yielding only incomplete tracks of foraging flights, our study has provided some new insights into the foraging ecology and behaviour of this Arctic seabird. Despite being burdened by the logger, parent little auks reached and probably foraged in the marginal sea ice zone at a minimum distance of $100 \mathrm{~km}$ from the colony (Fig. 4). The results confirm earlier suggestions that 

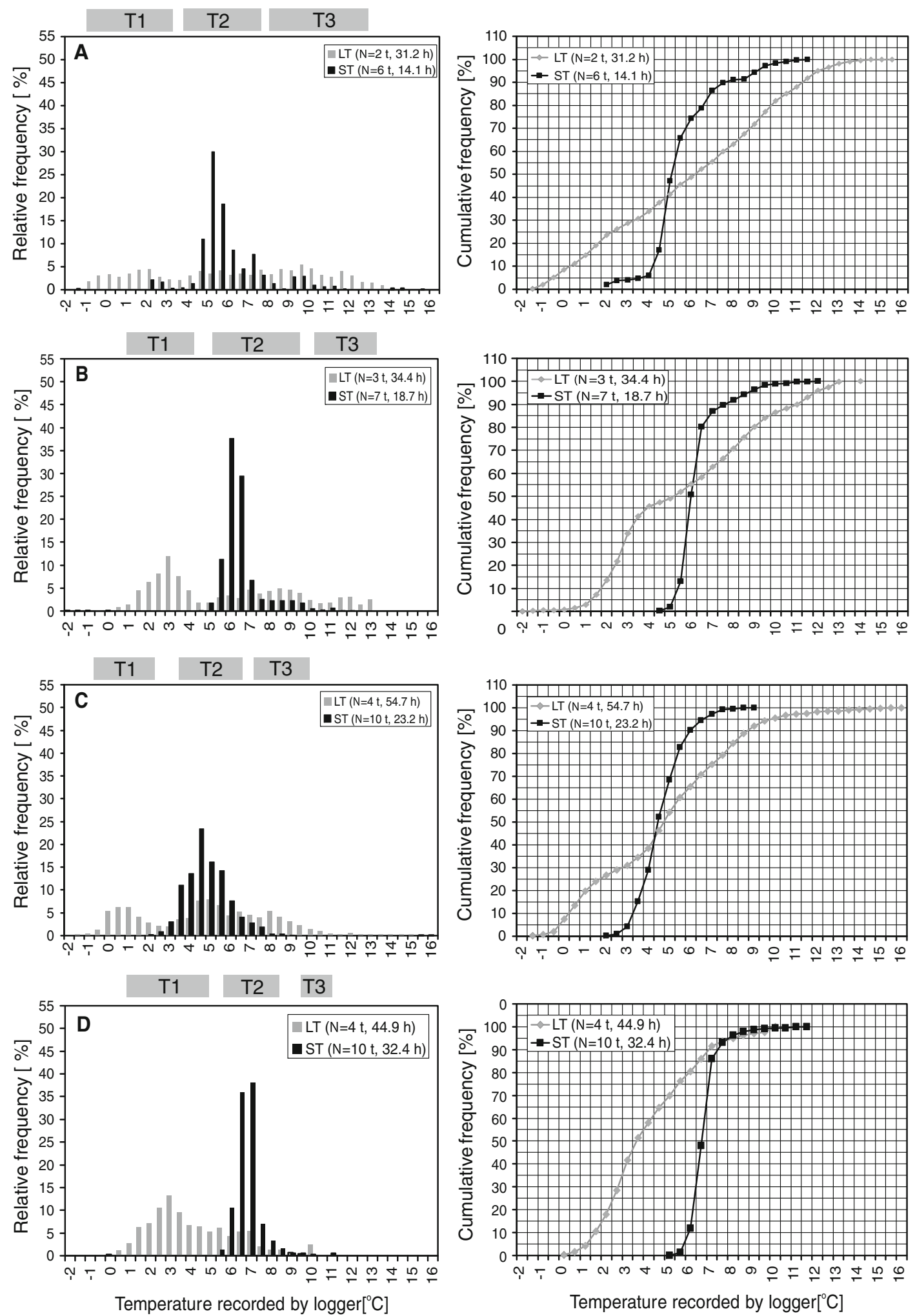

Fig. 3 Relative frequency (left) and cumulative frequency (right) of temperatures recorded by loggers during stays in the foraging area during short (ST) and long (LT) foraging trips of seven chick-rearing little auks in Magdalenefjorden in 2009. Bar T1 indicates the temperature level recorded only during the long trips, bar T2 the level of temperatures recorded during the long and short trips, and bar $\mathrm{T} 3$ the temper-

ature level reflecting flights between areas with temperature levels T1 and $\mathrm{T} 2$. These temperatures do not reflect actual air or water temperatures as the loggers were insulated by feathers to different extents. The number of trips analysed ( $t$ ) and the total time spent in the foraging area during them are given in parentheses 

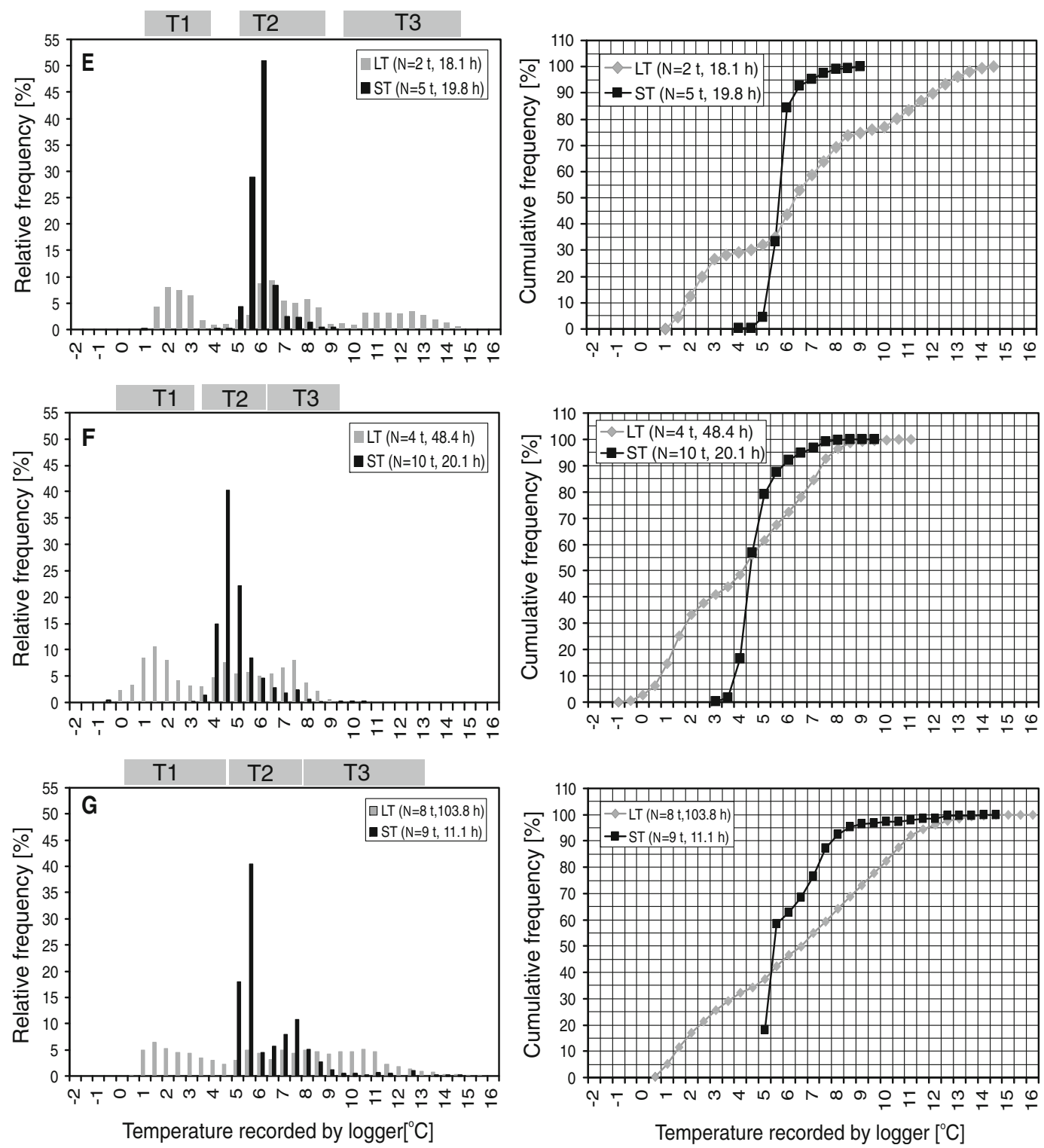

Fig. 3 continued

little auks breeding in Magdalenefjorden might be exploiting the marginal sea ice zone, since $5-18 \%$ of food loads collected in this colony in 2007, 2008 and 2009 consisted almost exclusively of the amphipod Apherusa glacialis (Kwasniewski et al. 2010; Jakubas et al. 2011; own unpublished data), which occurs in large concentrations only close to the sea ice (Hop et al. 2000, 2006).

The duration of the foraging trips of the two GPSequipped individuals was at least $9 \mathrm{~h}$ (assuming a similar number of stops on the way back to the colony), thus indicating that little auks reached the remote feeding grounds (i.e. marginal sea ice zone) during the long foraging trips. This was confirmed by the range of the lowest temperatures (close to $0^{\circ} \mathrm{C}$ ), which were recorded exclusively when the birds stayed at sea during the long trips (Figs. 2, 3). The larger range and smaller variation of temperatures recorded during the short trips (Figs. 2, 3) indicate that little auks exploited only warmer, nearby feeding grounds during such trips. Both the greater temperature variation and GPS tracks suggest that the birds make several stops during their long trips, possibly sampling the area with respect to the spatial variation of zooplankton biomass and abundance in the Greenland Sea (Blachowiak-Samolyk et al. 2008) and/or resting on the water before reaching more distant foraging grounds. During some trips at least, birds make the first stop close to the colony in the shelf break zone, considered to be an important foraging area of little auks (Stempniewicz 2001), and then continue their flight to reach distant feeding grounds near the marginal sea ice zone. The water temperatures recorded by the loggers did not exactly 


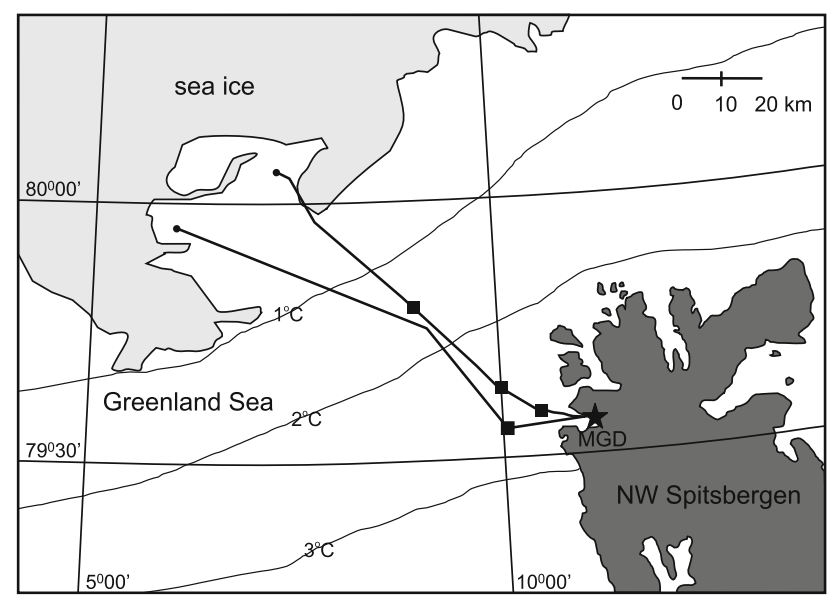

Fig. 4 The tracks of two GPS-equipped little auks recorded on 29.07.2009 (solid lines). The thin lines with numbers indicate SST isotherms (data for July 2009 from Reyn_Smith Olv2). The asterisk indicates the colony in Magdalenefjorden (MGD), and the squares show the areas where birds were recorded several times in succession. The light grey area indicates the extent of sea ice on 29.07.2009 (according to the ice map from Meteorologisk Institutt)

reflect the sea surface temperature distribution in July 2009 (Fig. 4) because the devices attached to the birds were partially insulated by their feathers. However, the difference in the temperatures recorded at the first and subsequent stops is evident and reflects the SST gradient between areas in the vicinity of colony and in the marginal ice zone (Figs. 2, 4). A similar pattern of SST decrease during the long trips was recorded in the nearby ( $75 \mathrm{~km}$ south of Magdalenefjorden) little auk colony in Kongsfjorden (Welcker et al. 2009 after Karnovsky et al., unpublished data). Also, observations from ship surveys in the Greenland Sea suggest that before reaching the ice edge, little auks stop and feed in the open water, exploiting local food-abundant areas like subsurface cold core eddies (Joiris and Falck 2011). However, the mean flight duration of little auks from East Greenland equipped with temperature loggers did not differ between long and short trips (Welcker et al. 2009), which suggests that they exploited the same feeding area during both types of trips. If the feeding conditions in the areas situated close to the colony are favourable, as in the case of East Greenland, little auks may forage there during long trips, spending the time saved on a shorter flight by resting longer.

Little auks breeding in Magdalenefjorden may be forced to exploit distant sea areas when feeding conditions close to the colony are suboptimal. To cover the extremely high energy demands of adults and chicks (Gabrielsen et al. 1991; Konarzewski et al. 1993), little auks from Spitsbergen have to focus on the large, energy-rich copepod Calanus glacialis associated with cold Arctic waters. Since the Magdalenefjorden shelf is influenced largely by warm Atlantic waters, dominated by its smaller and less calorific counterpart, C. finmarchicus (Stempniewicz 2001;
Kwasniewski et al. 2010), little auks from Magdalenefjorden provided their chicks with lower-energy meals but at a higher frequency than birds from the cold-water Hornsund (South Spitsbergen), where the copepods preferred by little auks are more abundant and available closer to the colony than is the case in Magdalenefjorden (Kwasniewski et al. 2010).

The durations of the long and short foraging trips recorded in the present study (means \pm SE $14.7 \pm 0.92$ and $3.3 \pm 0.18 \mathrm{~h}$, respectively) were longer than those reported from Hornsund (means \pm SE $11.7 \pm 0.77$ and $2.0 \pm$ $0.11 \mathrm{~h}$ ) by Welcker et al. (2009). Also, observations of individuals not burdened by loggers show that little auks in Magdalenefjorden spent more time foraging than the birds from Hornsund (Kwasniewski et al. 2010; Jakubas et al. 2011). This implies that little auks from Magdalenefjorden spent more time feeding at suboptimal foraging grounds or extended their foraging range. The exploitation of abundant food in the distant marginal sea ice zone at least partially supports the latter explanation. Additionally, birds may have to spend more time foraging in order to compensate for the additional energy costs incurred by longer travelling distances (Welcker et al. 2009).

The dual foraging strategy can also be viewed as a resource allocation between maximizing food delivery to the chicks (short trips) and self-maintenance (long trips; Weimerskirch 1998; Welcker et al. 2009). The occurrence in the chick diet of food items characteristic of the remote foraging areas, such as species associated with the sea ice zone (present study) and with the shelf break zone $150 \mathrm{~km}$ away from the colony (Steen et al. 2007), suggests that little auks are able to collect food for their chicks also in the distant areas reached during long trips. If the birds returned to the colony just after replenishing their own reserves and collecting food for chicks, they would be forced to travel with large amounts of food ingested, thereby substantially increasing their body mass and flight costs (Welcker et al. 2009). Thus, remaining at sea for extended periods during long trips may enable them to acquire, process and excrete the amount of food needed for self-maintenance completely before returning to the colony, reducing the costs of flight (Gabrielsen 1996; Welcker et al. 2009). Such a strategy may allow them to collect food for chicks at food-abundant, remote foraging grounds and to transport it cost-effectively back to the colony.

Our study revealed some of the constraints of using loggers on little auks related to stress and the extra loading of the parent birds. Despite the fact that the birds burdened by loggers were able to reach remote areas and deliver food to their chicks, their behaviour, chick feeding frequency and consequently, chick development were disturbed (Kidawa et al., in prep.). Although making up scarcely $3.4 \%$ of their body mass, the GPS loggers were probably still too heavy 
for little auks flying frequently to and from foraging grounds with up to 7-8 $\mathrm{g}$ of food in their gular pouches (Wojczulanis et al. 2006; Jakubas et al. 2007). To provide detailed information of the little auk's foraging strategy, further studies using improved devices, as well as a more representative sample size, are needed. Improved GPS loggers should be smaller and lighter. To minimize the stress related to recapture, remote data transmission using a base station in the colony should be used. To minimize drag, loggers should be reshaped (e.g. wedged; Bannasch et al. 1994).

Acknowledgments We are grateful to Gosia Jakimiak and Wojtek Iliszko for their irreplaceable help in the field work. We thank Zdzisław Błeński for creating application for visual inspection of temperature curves. We appreciate the improvements of English usage made by Peter Senn. Study was supported by grants from Polish Ministry of Science and Higher Education (1883/P01/2007/32, IPY/25/2007) and Norwegian Financial Mechanism (ALKEKONGE, PNRF-234-AI-1/07). The study was conducted under the permission of the Governor of Svalbard and the Norwegian Animal Research Authority.

Open Access This article is distributed under the terms of the Creative Commons Attribution Noncommercial License which permits any noncommercial use, distribution, and reproduction in any medium, provided the original author(s) and source are credited.

\section{References}

Arndt CE, Swadling KM (2006) Crustacea in Arctic and Antarctic Sea ice: distribution, diet and life history strategies. Adv Mar Biol 51:197-315

Bannasch R, Wilson RP, Culik B (1994) Hydrodynamic aspects of design and attachment of a back-mounted device in penguins. J Exp Biol 194:83-96

Blachowiak-Samolyk K, Søreide JE, Kwasniewski S, Sundfjord A, Hop H, Falk-Petersen S, Hegseth EN (2008) Hydrodynamic control of mesozooplankton abundance and biomass in northern Svalbard waters $\left(79-81^{\circ} \mathrm{N}\right)$. Deep-Sea Res II 55:2310-2324

Booth AM, Minot EO, Fordham RA, Imber MJ (2000) Coordinated food provisioning in the little Shearwater Puffinus assimilis haurakiensis: a previously undescribed foraging strategy in the Procellariidae. Ibis 142:139-158

Brown RGB (1976) The foraging range of breeding Dovekies, Alle alle. Can Field Nat 90:166-168

Catard A, Weimerskirch H, Cherel Y (2000) Exploitation of distant Antarctic waters and close shelf-break waters by whitechinned petrels rearing chicks. Mar Ecol Prog Ser 194:249-261

Chaurand T, Weimerskirch H (1994) The regular alternation of short and long foraging trips in the blue petrel Halobaena caerulea: a previously undescribed strategy of food provisioning in a pelagic seabird. J Anim Ecol 63:275-282

Gabrielsen GW (1996) Energy expenditure of breeding common murres. In: Montevecchi WA (ed) Studies of high latitude seabirds, 4. Trophic relationships and energetics of endotherms in cold ocean systems. Canadian Wildlife Service Occasional Paper 91. Ottawa, Canada, pp 49-58

Gabrielsen GW, Taylor JRE, Konarzewski M, Mehlum F (1991) Field and laboratory metabolism and thermoregulation in dovekies (Alle alle). Auk 108:71-78

Granadeiro JP, Nunes M, Silva M, Furness RW (1998) Flexible foraging strategy of Cory's shearwarter, Calonectris diomedea, during the chick rearing period. Anim Behav 56:1169-1176
Harding AMA, Pelt TIV, Lifjeld JT, Mehlum F (2004) Sex differences in little Auk Alle alle parental care: transition from biparental to parental-only care. Ibis 146:642-651

Hop H, Poltermann M, Loenne OJ, Falk-Petersen S, Korsnes R, Budgell WP (2000) Ice amphipod distribution relative to ice density and under-ice topography in the northern Barents Sea. Polar Biol 23:357-367

Hop H, Falk-Petersen S, Svendsen H, Kwasniewski S, Pavlov V, Pavlova O, Søreide JE (2006) Physical and biological characteristics of the pelagic system across Fram Strait to Kongsfjorden. Prog Oceanogr 71:182-231

Isaksen K (1995) The breeding population of Little Auk (Alle alle) in colonies in Hornsund and northwestern Spitsbergen. In: Isaksen K, Bakken V (eds) Seabird population in the northern Barents Sea. Meddelelser nr 135. Norsk PolarInstitutt, Oslo, pp 49-57

Jakubas D, Wojczulanis-Jakubas K, Walkusz W (2007) Response of Dovekie to changes in food availability. Waterbirds 30:421-428

Jakubas D, Głuchowska M, Wojczulanis-Jakubas K, Karnovsky NJ, Keslinka L, Kidawa D, Walkusz W, Boehnke R, Cisek M, Kwaśniewski S, Stempniewicz L (2011) Different foraging effort does not influence body condition and stress level in little auks. Mar Ecol Prog Ser (in press). doi:10.3354/meps09082

Joiris CR (2000) Summer at-sea distribution of seabirds and marine mammals in polar ecosystems: a comparison between the European Arctic seas and the Weddell Sea, Antarctica. J Marine Syst 27:267-276

Joiris CR, Falck E (2011) Summer at-sea distribution of little auks Alle alle and harp seals Pagophilus (Phoca) groenlandica in the Fram Strait and the Greenland Sea: impact of small-scale hydrological events. Polar Biol 34:541-548. doi:10.1007/s00300-010-0910-0

Karnovsky NJ, Kwasniewski S, Weslawski JM, Walkusz W, Beszczynska-Möller A (2003) Foraging behaviour if dovekies in a heterogeneous environment. Mar Ecol Prog Ser 253:289303

Konarzewski M, Taylor JRE, Gabrielsen GW (1993) Chick energy requirements and adult energy expenditures of dovekies (Alle alle). Auk 110:603-609

Kwasniewski S, Gluchowska M, Jakubas D, Wojczulanis-Jakubas K, Walkusz W, Karnovsky N, Blachowiak-Samolyk K, Cisek M, Stempniewicz L (2010) The impact of different hydrographic conditions and zooplankton communities on provisioning Dovekies along the West coast of Spitsbergen. Prog Oceanogr 87:72-82. doi:10.1016/j.pocean.2010.06.004

Steen H, Vogedes D, Broms F, Falk-Petersen S, Berge J (2007) Dovekies (Alle alle) breeding in a High Arctic fjord system: bimodal foraging strategies as a response to poor food quality? Polar Res 26:118-125

Stempniewicz L (2001) Alle alle Dovekie. J Birds Western Palearctic. Oxford University Press. BWP Update, vol 3, pp 175-201

Tremblay Y, Cherel Y, Oremus M, Tveraa T, Chastel O (2003) Unconventional ventral attachment of time-depth recorders as a new method for investigating time budget and diving behaviour of seabirds. J Exp Biol 206:1929-1940

Walczowski W, Piechura J (2007) Pathways of the Greenland Sea warming. Geophys Res Lett 34:L10608

Weimerskirch H (1998) How can a pelagic seabird provision its chick when relying on a distant resource? Cyclic attendance, foraging decision and body condition in sooty shearwaters. J Anim Ecol 67:99-109

Weimerskirch H, Chastel O, Chaurand T, Ackerman L, Hindermeyer X, Judas J (1994) Alternate long and short foraging trips in pelagic seabird parent. Anim Behav 47:472-476

Weimerskirch H, Cherel Y, Cuenot-Chaillet F, Ridoux V (1997) Alternative foraging strategies and resources allocation by male and female wandering albatrosses. Ecology 78:2051-2063 
Welcker J, Harding AMA, Karnovsky NJ, Steen H, Strøm H, Gabrielsen GW (2009) Flexibility in the bimodal strategy of a high Arctic alcid, the dovekie Alle alle. J Avian Biol 40:388-399

Węsławski JM, Stempniewicz L, Mehlum F, Kwaśnieski S (1999) Summer feeding strategy of the little auk (Alle alle) from Bjørnøya, Barents Sea. Polar Biol 21:129-134

Wilson RP, Putz K, Peters G, Culik B, Scolaro JA, Charrassin JB, Ropert-Coudert Y (1997) Long-term attachment of transmitting and recording devices to penguins and other seabirds. Wildl Soc Bull 25:101-106

Wojczulanis K, Jakubas D, Walkusz W, Wennerberg L (2006) Differences in food delivered to chicks by males and females of little auks (Alle alle) on South Spitsbergen. J Ornithol 147:543-548

Wojczulanis-Jakubas K, Jakubas D, Karnovsky NJ, Walkusz W (2010) Foraging strategy of dovekies under divergent conditions on feeding grounds. Polar Res 29:22-29 